\title{
Gyermekkori traumatizáció, disszociáció és szándékos fizikai önsértő viselkedés borderline személyiségzavarban
}

\author{
Merza Katalin ${ }^{1}$ - Harmatta János dr. ${ }^{2}$ \\ Papp Gábor dr. ${ }^{3}$ - Kuritárné Szabó Ildikó dr. ${ }^{1}$ \\ ${ }^{1}$ Debreceni Egyetem, Népegészségügyi Kar, Magatartástudományi Intézet, \\ Klinikai és Egészségpszichológiai Tanszék, Debrecen \\ ${ }^{2}$ Országos Orvosi Rehabilitációs Intézet, Tündérhegyi Pszichoszomatikus \\ és Pszichoterápiás-rehabilitációs Osztály, Budapest \\ ${ }^{3}$ Debreceni Egyetem, Bölcsészettudományi Kar, Pszichológia Intézet, Debrecen
}

Bevezetés: A súlyos és komplex gyermekkori traumatizáció lehetséges felnőttkori kimeneteleinek egyike a borderline személyiségzavar. A disszociatív jelenségek és a szándékos fizikai önsértések feltehetően a gyermekkori traumatizáció következményeként részei a borderline tünettannak.

Célkitüzés: A vizsgálat célja a borderline betegek körében megjelenő disszociatív jelenségek és önsértések felmérése, valamint a disszociáció, az önsértés és a gyermekkori bántalmazás közötti kapcsolat feltárása volt.

Módszer: A vizsgálati mintát 80 hospitalizált borderline páciens és 73 hospitalizált depressziós kontrollszemély alkotta. A gyermekkori traumatikus élményeket, a disszociációt és az önsértő viselkedést kérdőívek segítségével mértük fel. Eredmények: A borderline személyiségzavarban szenvedő betegek gyermekkorukban súlyos, multiplex traumatizációt éltek át. A különböző traumatípusok halmozódása és a behatolással járó szexuális abúzus a disszociáció rizikófaktorainak bizonyultak. Az önsértő viselkedés kialakulásának esélyét a gyermekkori traumatikus élmények halmozódása és a disszociáció jelentősen növelték.

Következtetés: A borderline személyeknél a disszociatív tünetek és munkamódok a szándékos fizikai önsértéssel együtt a traumatikus kóreredetre figyelmeztetnek, és kitüntetett figyelmet igényelnek.

Orv Hetil. 2017; 158(19): 740-747.

Kulcsszavak: borderline személyiségzavar, gyermekkori traumatizáció, disszociáció, önsértés

\section{Childhood traumatization, dissociation and nonsuicidal self-injurious behavior in borderline personality disorder}

Introduction: Childhood traumatization plays a significant role in the etiology of borderline personality disorder. Studies found a significant association between childhood traumatization, dissociation, and nonsuicidal self-injurious behavior.

Aim: The aim of our study was to assess dissociation and nonsuicidal self-injury among borderline inpatients and to reveal the association between childhood traumatization, dissociation, and self-injurious behavior.

Method: The sample consisted of 80 borderline inpatients and 73 depressed control patients. Childhood traumatization, dissociation and self-injurious behavior were assessed by questionnaires.

Results: Borderline patients reported severe and multiplex childhood traumatization. Cumulative trauma score and sexual abuse were the strongest predictors of dissociation. Furthermore, we have found that cumulative trauma score and dissociation were highly predictive of self-injurious behavior.

Conclusion: Our results suggest that self-injurious behavior and dissociation in borderline patients can be regarded as indicators of childhood traumatization.

Keywords: borderline personality disorder, childhood traumatization, dissociation, nonsuicidal self-injury

Merza K, Harmatta J, Papp G, K Szabó I. [Childhood traumatization, dissociation and nonsuicidal self-injurious behavior in borderline personality disorder]. Orv Hetil. 2017; 158(19): 740-747.

(Beérkezett: 2017. február 25.; elfogadva: 2017. március 28.) 


\section{Rövidítések}

DISQ-H = Magyar Disszociáció Kérdőív; SCID-I = Strukturált klinikai interjú a DSM-IV I. tengely zavarainak felmérésére; SCID-II = Strukturált klinikai interjú a DSM-IV II. tengelyén található személyiségzavarok felmérésére

A borderline személyiségzavar a mentális ellátásban jól ismert, súlyos személyiségzavar. A borderline betegek aránya az utóbbi évtizedekben növekvő tendenciát mutat, a kórkép jelentőségére nem a betegek átlagpopulációban való előfordulása $(0,5-5,9 \%)[1]$, hanem a klinikumban való túlsúlyuk (a járóbetegek 15-25\%-a, a fekvőbetegek 15-18\%-a borderline) [2] és a kezelésük jelentette nehézségek mutatnak rá. A borderline páciensek tipikusan fiatal nőbetegek, akik az identitásérzet, az önszabályozás (érzelemszabályozás, impulzuskontroll, önértékérzet szabályozása) és az interperszonális kapcsolatok problémáival küzdenek. A betegekre jellemző instabilitás az intenzív és viharos interperszonális kapcsolatok terén, valamint az érzelmi és hangulati élet vonatkozásában is megnyilvánul. Gyakran keresnek önként orvosi, pszichológusi segítséget, az ambuláns kezelések mellett gyakran szorulnak osztályos kezelésre, és az impulzív, kockázatkereső, öndestruktív cselekményeik miatt gyakran részesülnek sürgősségi ellátásban. Tüneteik részben magából a személyiségzavarból, illetve a személyiségfejlődést deformáló korai gyermekkori traumatizációból származnak, részben az átfogó szabályozási zavarból következő diszfunkcionális megküzdési próbálkozásként értelmezhetőek. A borderline személyiségzavarhoz gyakran társulnak más pszichiátriai kórképek, a borderline betegek átlagosan 3,4 aktuálisan fennálló I. tengely diagnózissal rendelkeznek, és átlagosan 2,3 másik személyiségzavar kritériumait teljesítik [3]. A nehezen gyógyuló szerhasználók, a szorongásos zavarokban, konverziós zavarban, evészavarokban, a krónikus vagy epizodikus hangulatzavarban szenvedő betegek sokszor borderline személyiségszerveződéssel rendelkeznek. A borderline személyiségzavar jelentős szenvedést okoz a pácienseknek és a hozzátartozóiknak, nagy terhet ró az egészségügyre, a szakszemélyzet számára pedig frusztrációt és nehézségforrást jelenthet.

\section{Gyermekkori traumatizáció}

A gyermekkori traumatizáció sokféle pszichiátriai kórkép kialakulásában tölt be oki szerepet [4]. A súlyos és komplex gyermekkori traumatizáció (interakcióban a biológiai tényezőkkel) lehetséges felnőttkori kimeneteleinek egyike a borderline személyiségzavar. A külföldi vizsgálatokban [5-7] és a saját hazai kutatásunkban [8] is a kontrollcsoportokhoz képest a borderline betegek körében szignifikánsan gyakoribb a traumatikus események előfordulása. A saját kutatásunkból származó eredmények alapján a borderline páciensek 88\%-át érzelmileg, 65\%-át fizikailag, 56\%-át szexuálisan bántalmazták gyermekko- rában. 86\%-uk számolt be 18 éves kor előtt elszenvedett érzelmi és fizikai elhanyagolásról, $80 \%$-uk pedig a szülőktőll való hosszas szeparációról, valamint 78\%-uk volt szemtanúja családon belüli erôszakos cselekményeknek [8]. A szexuálisan bántalmazott borderline betegek döntő többsége a legsúlyosabb paraméterekkel jellemezhető, apa vagy férfi gondozó által elkövetett (49\%), behatolással járó $(80 \%)$, havi rendszerességgel történő $(40 \%)$ és akár hatéves kor előtt elkezdődő (38\%) szexuális bántalmazást élt át. Az apán/férfi gondozón kívül gyakran (40\%) az áldozat számára ismert személy vagy távolabbi családtag (nagyapa, nagybácsi) a szexuális bántalmazás elkövetője, sőt nem ritka, hogy több elkövető $(42,2 \%)$ is azonosítható $[8,9]$. A felnőttkori borderline pszichopatológia legerősebb prediktorainak saját eredményeink szerint a gyermekkorban átélt szexuális és fizikai bántalmazás, valamint az elhanyagolás bizonyultak [8].

\section{Disszociáció}

A mentális és viselkedészavarokat osztályozó nozológiai rendszer, a DSM-5 [10] a disszociáció patológiás formáit a memória, az identitás és a tudat dezintegrációjaként írja le. A patológiás disszociáció tünetei közé sorolható a derealizáció, a deperszonalizáció, a disszociatív amnézia, illetve az identitásérzetben bekövetkező változások [11]. Enyhe disszociatív élmények számos pszichiátriai kórképben előfordulnak, sőt az átlagnépességben is megjelenhetnek olyan különleges körülmények hatására, mint az alvásmegvonás, betegség, szerabúzus és szenzoros depriváció [12]. A patológiás disszociatív jelenségek feltehetően a gyermekkori traumatizáció következményeként részei a borderline tünettannak [13-15]. A traumatizáció alatt a gyermek sem harcolni, sem menekülni nem tud, így a disszociáció segítségével kilép a helyzetből, nem éli át a társuló testi-lelki fájdalmat, késóbb pedig nem emlékszik a traumára [16]. Az abúzus súlyossági paramétereivel együtt nő a disszociáció mértéke, a társuló disszociatív zavarok esetén a legsúlyosabb abúzustörténettel és a legzavartabb kötődési státusszal kell számolni $[13,17,18]$.

\section{Önsértö viselkedés}

A szándékos fizikai önsértés akaratlagosan elkövetett, többnyire alacsony letalitású cselekmény, amelynek során a betegnek nem áll szándékában véget vetni az életének [19]. Az önsértő viselkedés a borderline személyiségzavar egyik központi jellemzője, magasan diszkriminatív értékú diagnosztikus kritérium [20], amelyre gyakran hivatkoznak a kórkép viselkedéses specifikumaként [21]. Az önsértő viselkedés és a gyermekkori traumatikus élmények között szoros együttjárást találtak a vizsgálatok nemcsak a borderline populációban [22-25], hanem a más pszichiátriai diagnózisú páciensek csoportjában [26], valamint az átlagpopulációban is [27]. A kutatások többségében az önsértések legerősebb prediktorának a 
súlyosabb paraméterekkel jellemezhető, korai kezdetű, gondozó által elkövetett, kényszerítéssel történt szexuális abúzus bizonyult [27-31]. Az önsértés maladaptív megküzdésként értelmezhető, elsősorban patológiás érzelemszabályozó szerepet tölt be: felülírja, elfedi az érzelmi fájdalmat, segíthet kifejezni, csillapítani, igazolni az elviselhetetlen dühöt, feszültséget. Az önsértés továbbá a disszociatív állapotokra adott közvetlen válaszként értelmezhető, a beteg a disszociáció következtében fellépő deperszonalizáció élményétől az önsértés segítségével próbál megszabadulni [13, 16].

A vizsgálat célja a borderline betegek körében megjelenő disszociatív jelenségek és a szándékos fizikai önsértések felmérése, valamint a disszociáció, az önsértés és a gyermekkori bántalmazás közötti kapcsolat feltárása.

\section{Módszer}

A kutatást az Egészségügyi Tudományos Tanács Tudományos és Kutatásetikai Bizottsága engedélyezte.

\section{Vizsgált személyek}

A kutatás 2013-ban, egy éven keresztül zajlott nyolc budapesti és vidéki pszichiátriai osztály összesen 171 páciensének bevonásával.

A vizsgált személyek 18 és 50 év közötti, legalább átlagos intellektusú pszichiátriai fekvőbetegek voltak. A mintába kerülés szempontjából kizáró oknak számított bármely pszichotikus zavar, bipoláris affektív zavar, illetve kognitív károsodás. A vizsgálati csoportokba sorolás a SCID-I-II strukturált diagnosztikus interjúk magyar változatának (Strukturált klinikai interjú a DSM-IV zavarainak felmérésére) $[32,33]$ segítségével történt. Az interjúk alapján a 171 betegből 18-at zártunk ki a vizsgálati mintából, mert nem feleltek meg a beválogatási kritériumoknak. A SCID-II interjú alapján a borderline diagnózis teljesüléséhez szükséges öt vagy annál több kritériumot elérő páciensek alkották a borderline vizsgálati csoportot. A depressziós kontrollcsoportba a SCID-I interjú alapján major depressziós zavarral diagnosztizált betegek kerültek, akik nem teljesítették egyetlen személyiségzavarnak sem a kritériumait.

\section{Vizsgálati eszközök}

A gyermekkori traumatikus élményeket a 42 itemból álló Traumatikus Elözmények Kérdöível (Traumatic Antecedents Questionnaire) [34] mértük fel. A kérdőív három életkori szakaszban, kisgyermekkorban (0-6 év), kisiskoláskorban (7-12 év) és serdülőkorban (13-18 év) vizsgálja a kedvezőtlen élmények széles skáláját (elhanyagolás, szeparáció, érzelmi/fizikai/szexuális bántalmazás, családon belüli erószak szemtanújaként megélt fenyegetettség).
A szexuális bántalmazás súlyossági paramétereinek részletesebb vizsgálatára a Korai Traumatikus Élmények Kérdőiv [35] szexuális abúzus alskáláját alkalmaztuk. A kérdőív három életkori szakaszban - kisgyermekkorban (0-6 év), kisiskoláskorban (7-12 év) és serdülőkorban (13-18 év) - méri fel a bántalmazás elkövetőjét, módját (például intim testrészek fogdosása, orális/anális/vaginális behatolással járó szexuális erőszak) és gyakoriságát.

A fizikai önsértések módozatát (például falcolás, önütlegelés, égetés), számát, súlyosságát, életkori kezdetét, illetve a szuicid kísérletek számát az Ottawa Önsértő Kérdö́nvel [36] összesítettük.

A disszociáció felmérésére a 63 itemből álló Magyar Disszociáció Kérdőivet (DISQ-H) alkalmaztuk [37]. A DISQ-H alskálái a következők: identitászavar („Megesik, hogy úgy érzem, valaki más vagyok”), a viselkedés, a gondolkodás és az érzelmek feletti kontrollvesztés ( „Megesik, hogy zavarodottnak érzem magam”), amnézia („Előfordul, hogy hosszabb időszakok eseményei esnek ki az emlékezetemből”), abszorpció, vagyis teljes figyelmi bevonódás („Olyan tisztán vissza tudok emlékezni régebben történt eseményekre, hogy úgy érzem, újra átélem őket”). A kérdoóiv kitöltése során a válaszadónak egy ötfokú Likert-skálán kell bejelölnie, hogy az adott állítást mennyire érzi igaznak saját magára. A teszt végső pontszámát az egyes tételekre adott pontértékek átlaga képezi.

\section{Eredmények}

A végleges vizsgálati mintát összesen 153 fó alkotta, 80 hospitalizált borderline páciens és 73 hospitalizált depressziós kontrollszemély. A minta demográfiai jellegzetességeit az 1. táblázat foglalja össze. A független mintás T-próba eredménye szerint a borderline páciensek szignifikánsan fiatalabbnak bizonyultak, mint a depressziós kontrollszemélyek $(\mathrm{t}(15 \mathrm{l})=-9,59, \mathrm{~F}=31,07, \mathrm{p}<0,001)$. A $\chi^{2}$-próba alapján szignifikáns különbségeket találtunk a csoportok között a családi állapot $\left(\chi^{2}(4)=69,69\right.$, $\mathrm{p}<0,001)$ és a foglalkoztatottság $\left(\chi^{2}(6)=42,28, \mathrm{p}<0,001\right)$ tekintetében, a borderline betegek között kevesebb volt a házas és több a munkanélküli személy. A csoportokban az iskolázottság $\left(\chi^{2}(2)=2,184, \mathrm{p}=0,335\right)$ hasonlóan alakult, illetve mindkét csoportban női túlsúly tapasztalható $\left(\chi^{2}(1)=0,220, \mathrm{p}=0,639\right)$, ami a klinikai realitást képezi le, hiszen a borderline személyiségzavar és a depresszió is főként nőket érintő kórkép.

Vizsgálatunkban felmértük a betegek pszichiátriai kórtörténetének életkori kezdetét, illetve a pszichiátriai osztályos kezelések számát. A Mann-Whitney-próba alapján a borderline páciensek szignifikánsan fiatalabb életkorban kerültek a pszichiátriai ellátórendszerbe ( $\mathrm{U}=$ $945,5, \mathrm{z}=-7,22, \mathrm{p}<0,001)$, első kezelésük idején átlagosan 23,2 $\pm 10,25(\mathrm{Mdn}=19)$ évesek voltak, míg a depressziós kontrollszemélyek 35,9 $\pm 8(\mathrm{Mdn}=35)$ évesek voltak. A hospitalizációk számában a két csoport nem 
1. táblázat |A minta demográfiai jellemzői

\begin{tabular}{|c|c|c|c|c|}
\hline $\begin{array}{l}\text { Demográfiai } \\
\text { jellemzók }\end{array}$ & $\begin{array}{l}\text { Borderline } \\
(\mathrm{n}=80)\end{array}$ & $\begin{array}{l}\text { Depressziós } \\
(\mathrm{n}=73)\end{array}$ & $\chi^{2}$ & $\mathrm{p}$ \\
\hline $\begin{array}{l}\text { Életkor } \\
\text { (átlag, szórás)* }\end{array}$ & $30,5 \pm 10,87$ & $44,3 \pm 5,91$ & & $<0,001$ \\
\hline Nem & & & $\begin{array}{l}0,22 \\
(\mathrm{df}=1)\end{array}$ & 0,639 \\
\hline Férfi & $12(15 \%)$ & $13(17,8 \%)$ & & \\
\hline Nö & $68(85 \%)$ & $60(82,2 \%)$ & & \\
\hline Családi állapot & & & $\begin{array}{l}69,69 \\
(\mathrm{df}=4)\end{array}$ & $<0,001$ \\
\hline Egyedülálló & $50(62,5 \%)$ & $6(8,2 \%)$ & & \\
\hline Házas & $3(3,8 \%)$ & $42(57,5 \%)$ & & \\
\hline $\begin{array}{l}\text { Élettársi } \\
\text { kapcsolatban él }\end{array}$ & $10(12,5 \%)$ & $6(8,2 \%)$ & & \\
\hline Elvált & $14(17,5 \%)$ & $14(19,2 \%)$ & & \\
\hline Özvegy & $3(3,8 \%)$ & $5(6,9 \%)$ & & \\
\hline Iskolai végzettség & & & $\begin{array}{l}2,18 \\
(\mathrm{df}=2)\end{array}$ & 0,335 \\
\hline Általános iskola & $19(23,8 \%)$ & $13(17,8 \%)$ & & \\
\hline Középiskola & $51(63,8 \%)$ & $45(61,6 \%)$ & & \\
\hline Egyetem & $10(12,5 \%)$ & $15(20,5 \%)$ & & \\
\hline Foglalkoztatottság & & & $\begin{array}{l}42,28 \\
(\mathrm{df}=6)\end{array}$ & $<0,001$ \\
\hline Munkanélküli & $30(37,5 \%)$ & $14(19,2 \%)$ & & \\
\hline Leszázalékolt & $13(16,3 \%)$ & $39(53,4 \%)$ & & \\
\hline Teljes állás & $6(7,5 \%)$ & $6(8,2 \%)$ & & \\
\hline Félállás & $6(7,5 \%)$ & $1(1,4 \%)$ & & \\
\hline $\begin{array}{l}\text { Alkalmi } \\
\text { munkavégző }\end{array}$ & $4(5,0 \%)$ & $0(0 \%)$ & & \\
\hline Diák & $16(20,0 \%)$ & $1(1,4 \%)$ & & \\
\hline Egyéb & $5(6,3 \%)$ & $1216,4 \%)$ & & \\
\hline
\end{tabular}

${ }^{*} \mathrm{~F}=31,073, \mathrm{t}=-9,59, \mathrm{df}=151$

különbözött szignifikánsan $(\mathrm{U}=2872,5, \mathrm{z}=-0,18$, $\mathrm{p}=0,860)$, ugyanakkor a jóval fiatalabb borderline betegeket gyakrabban $-5,76 \pm$ 7,7 $(\mathrm{Mdn}=3)$ alkalommal kezelték pszichiátriai osztályon, mint a depressziós pácienseket, akiket 3,79 $\pm 2,95(\mathrm{Mdn}=3)$ alkalommal hospitalizáltak.

\section{Gyermekkori traumatizáció és borderline személyiségzavar}

A gyermekkori traumatípusok, illetve a szexuális bántalmazás súlyossági paramétereinek a mintánkban való előfordulását egy korábbi cikkünkben már részletesen ismertettük [8]. Jelen vizsgálatban a kumulatív traumapontszám tekintetében hasonlítottuk össze a csoportokat, amely 0-6-ig terjedhet, és azt fejezi ki, hogy a vizsgált személy gyermekkora során hány fajta traumatípust szenvedett el az általunk felmért hat kategóriából (szexuális/fizikai/érzelmi bántalmazás, elhanyagolás, szeparáció, családon belüli fizikai erőszak szemtanújaként megélt fenyegetettség). A Mann-Whitney-próba szignifikáns különbséget mutatott a két csoport kumulatív traumapontszámai között ( $\mathrm{U}=732,5, \mathrm{z}=-8,14, \mathrm{p}<0,001)$, a borderline betegek átlagosan $5 \pm 1,17(\mathrm{Mdn}=5)$, míg a depressziós kontrollszemélyek átlagosan 2,63 $\pm 1,58$ $(\mathrm{Mdn}=3)$ gyermekkorban átélt traumatípusról számoltak be.

\section{Disszociáció és borderline személyiségzavar}

A vizsgálatunkba bevont borderline és depressziós páciensek disszociáció-pontszámainak összehasonlítását a 2. táblázat mutatja be. A Mann-Whitney-próba alapján a Disszociáció Kérdőíven elért pontszám $(\mathrm{U}=1215,0, \mathrm{z}=$ $-6,23, p<0,001)$, illetve a kérdőív egyes alskáláin elért pontszámok: Identitászavar $(\mathrm{U}=1416,0, \mathrm{z}=-5,49$, $\mathrm{p}<0,001)$, Kontrollvesztés $(\mathrm{U}=1135,0, \mathrm{z}=-6,52$, $\mathrm{p}<0,001$ ), Amnézia ( $\mathrm{U}=1787,0, \mathrm{z}=-4,14, \mathrm{p}<0,001)$, Abszorpció ( $\mathrm{U}=1744,5, \mathrm{z}=-4,30, \mathrm{p}<0,001$ ) szignifikánsan magasabbnak bizonyultak a borderline csoportban.

\section{Disszociáció és a gyermekkori traumatizáció}

A disszociáció és a gyermekkori bántalmazás közötti kapcsolatot regressziószámítás segítségével vizsgáltuk. A modellbe a Disszociáció Kérdőíven elért átlagpontszámot függő változóként, a gyermekkori traumatizáció egyes típusait (fizikai, szexuális, érzelmi abúzus, elhanyagolás, szeparáció, családon belüli bántalmazás szemtanújaként megélt fenyegetettség), a szexuális bántalmazás paramétereit (elkövető, módozat, kezdet, gyakoriság),

2. táblázat |A disszociáció-pontszámok alakulása a mintában

\begin{tabular}{lccc|ccc|ccc}
\hline & \multicolumn{3}{c|}{ Borderline $(\mathrm{n}=80)$} & \multicolumn{3}{c|}{ Depressziós $(\mathrm{n}=73)$} & \multicolumn{3}{c}{ Statisztikai eljárás } \\
\cline { 2 - 11 } & $\mathrm{Mdn}$ & $\mathrm{M}$ & $\mathrm{SD}$ & $\mathrm{Mdn}$ & $\mathrm{M}$ & $\mathrm{SD}$ & $\mathrm{U}$ & $\mathrm{z}$ & $\mathrm{p}$ \\
\hline Disszociáció Kérdő́ven elért pontszám & 2,98 & 2,72 & 0,76 & 1,81 & 1,91 & 0,54 & 1215,5 & $-6,23$ & $<0,001$ \\
Identitászavar & 2,68 & 2,56 & 0,86 & 1,60 & 1,78 & 0,59 & 1416,0 & $-5,49$ & $<0,001$ \\
Kontrollvesztés & 3,22 & 3,07 & 0,93 & 1,94 & 2,04 & 0,60 & 1135,0 & $-6,52$ & $<0,001$ \\
Amnézia & 2,36 & 2,51 & 0,99 & 1,64 & 1,83 & 0,64 & 1787,0 & $-4,14$ & $<0,001$ \\
Abszorpció & 2,83 & 2,86 & 0,81 & 2,17 & 2,24 & 0,83 & 1744,5 & $-4,30$ & $<0,001$ \\
\hline
\end{tabular}


valamint a kumulatív traumapontszámot független változóként vontuk be. A modell felállításához az Enter módszert használtuk. A modell alapján a vizsgált függő és független változók között kapcsolat mutatható ki, a prediktorok a disszociáció varianciájának 54\%-ára adtak magyarázatot $\left(\mathrm{F}(24,128)=6,18, \mathrm{p}<0,001, \mathrm{R}^{2}=0,54\right)$. A disszociáció kialakulásának esélyét a kumulatív traumapontszám (Beta $=0,342, \mathrm{t}=2,973, \mathrm{p}=0,004)$ és a behatolással járó szexuális bántalmazás $($ Beta $=0,326, \mathrm{t}=$ $2,728, \mathrm{p}=0,007)$ növelték szignifikáns mértékben.

\section{Önsértés és borderline személyiségzavar}

A $\chi^{2}$-próba alapján a borderline csoportban a depressziós kontrollcsoporthoz viszonyítva szignifikánsan több beteg számolt be arról, hogy élete során elkövetett legalább egy önsértő cselekedetet $\left(\chi^{2}(1)=86,69, \mathrm{p}<0,001\right)$, a borderline-ok közül 63 fó volt önsértő, a depressziósok közül 3 fó.

A Mann-Whitney-próba szignifikáns különbségeket mutatott ki a csoportok között az önsértő cselekedetek száma $(\mathrm{U}=21,00, \mathrm{z}=-2,27, \mathrm{p}=0,023)$ és életkori kezdete $(U=0,000, z=-2,92, p<0,001)$ tekintetében. A borderline betegek életük során átlagosan 30,46 \pm 34,1 $(\mathrm{Mdn}=15)$ alkalommal sebezték meg önmagukat, míg a depressziós kontrollszemélyek ennél jóval kevesebbszer, átlagosan 2,33 \pm 1,53 (Mdn $=2$ ) alkalommal. A borderline betegek 30 évvel korábban, átlagosan $16,62 \pm 6,17(\mathrm{Mdn}=15)$ éves korban bocsátkoztak elöször önsebzésbe, míg a depressziós kontrollszemélyek átlagéletkora az első önsebzés idején $46 \pm 4$ év (Mdn = 46) volt.

\section{Önsértés, gyermekkori traumatizáció és disszociáció}

Az önsértés, a gyermekkori traumatizáció és a disszociáció közti kapcsolatot logisztikus regressziószámítás segítségével vizsgáltuk. A modellbe az önsértő cselekedeteket függő változóként, a gyermekkori traumatizáció egyes típusait (fizikai, szexuális, érzelmi abúzus, elhanyagolás, szeparáció, családon belüli bántalmazás szemtanújaként megélt fenyegetettség), a szexuális bántalmazás paramétereit (elkövető, módozat, gyakoriság, kezdet), a kumulatív traumapontszámot, valamint a disszociációpontszámot független változóként vontuk be. A modell felállításához az Enter módszert használtuk. A logisztikus regressziós modell statisztikailag szignifikánsnak bizonyult $\left(\chi^{2}(26)=148,54, \mathrm{p}<0,001\right)$. A modell a függő változó varianciájának $83,4 \%$-át (Nagelkerke $\mathrm{R}^{2}$ ) magyarázza, és 94,1\%-os sikerrel képes bejósolni a függő változót. Az önsértések szignifikáns rizikófaktorainak a diszszociáció-átlagpontszám $(\operatorname{Exp}(\mathrm{B})=4,82, \mathrm{p}=0,014)$ és a kumulatív traumapontszám $(\operatorname{Exp}(\mathrm{B})=2,55, \mathrm{p}=0,019)$ bizonyultak.

\section{Megbeszélés}

Vizsgálatunk célja a borderline betegek körében megjelenő disszociatív jelenségek és szándékos fizikai önsértések felmérése, valamint a gyermekkori bántalmazás, a disszociáció és az önsértés közötti kapcsolat feltárása volt.

Kutatásunk a borderline személyiségzavarban szenvedő betegek súlyos, multiplex traumatizáltságát bizonyítja, az általunk felmért hat traumatikus élménytípus (szexuális, fizikai és érzelmi bántalmazás, elhanyagolás, szülőktől való hosszas szeparáció, családon belüli bántalmazás szemtanújaként megélt fenyegetettség) közül a vizsgálatba bevont borderline személyek 18 éves koruk előtt átlagosan ötöt szenvedtek el! Ráadásul - a másutt közölt adataink szerint - a borderline betegek élettörténetében tipikusan a legsúlyosabb bántalmazásformák fordulnak elő [8], amely új megvilágításba helyezi a sokszor „nehéz betegként” aposztrofált borderline személyeket, akik embert próbáló traumatikus élmények közepette próbálták túlélni a sokszor szinte kibírhatatlan bántalmazást, elhanyagolást, támasznélküliséget. A komplex traumatizáció súlyosabb állapotot eredményez, jelentősen rontja a prognózist és a pszichoszociális funkciószintet, amelyet a vizsgált személyek demográfiai jellemzői is mutatnak. Adataink a jéghegy csúcsaként jelzik a gyermekkori traumatizáció járványszerü elterjedtségét [38].

Vizsgálatunkban a borderline betegek súlyos, a patológiás disszociáció jelenségkörébe sorolható disszociatív élményekról számoltak be, amelyek a magyar átlagpopuláció csupán 10\%-ában fordulnak elő [37]. Eredményeink megegyeznek a külföldi vizsgálatokból származó adatokkal, amelyek a borderline személyiségzavarban szenvedő betegek körében a pszichiátriai zavarokban szenvedő és egészséges kontrollcsoportokhoz képest súlyosabb és gyakoribb disszociatív tüneteket találtak [39, 40]. A borderline páciensek disszociatív élményei közé tartoznak az identitásérzetben bekövetkezett változások, a deperszonalizációs/derealizációs élmények, a kontrollvesztett állapotok és az emlékezetkiesések. A klinikai képben való megjelenést tekintve a disszociatív müködésmód a nem vagy kevésbé disszociáló borderline betegekhez képest még erôteljesebb instabilitást és impulzivitást, következésképpen súlyosabb interperszonális konfliktusokat és gyakoribb/súlyosabb öndestruktív cselekedeteket jelent. A beteget triggerelik a múlt traumatikus élményeihez kondicionálódott jelzőingerek, aki így látszólag akár jelentéktelen történésekre is mindent elárasztó érzelmekkel és a helyzethez nem illeszkedő viselkedéssel reagálhat [41]. A disszociatív jellemzőkkel rendelkező (traumatizált) borderline betegek kezelése tehát sajátos kihívások elé állítja a szakembert. A terápiás munkát a gondoskodó személybe (a terapeutába) vetett bizalom törékenysége, valamint a szélsőségesen negatív (bemocskolt, tisztátalan, büntudatos) önkép tovább nehezíti. 
Eredményeink alapján a disszociáció legfőbb bejósló tényezóinek a kumulatív traumapontszám és a behatolással járó szexuális bántalmazás bizonyultak, vagyis vizsgálatunkban is igazolódott, hogy a gyermekkori traumatikus események halmozódása, valamint a súlyosabb szexuális abúzus szoros kapcsolatban áll a súlyosabb diszszociatív tünetképzéssel $[17,42,43]$. A disszociáció, ami a traumatizáció központi jellemzője, rövid távon adaptív, mert elkülönítve tárolja a mindennapi élettel és a traumatikus élményekkel kapcsolatos tartalmakat, hosszú távon azonban maladaptívvá válik, akadályozza a traumatikus élmények feldolgozását, továbbá a traumatikus emlékek a már említett módon a traumához kondicionálódott jelzőingerek hatására intruzív módon betörhetnek a tudatba, akár át is vehetik a viselkedés irányítását [41].

Mintánkban a borderline páciensek több mint háromnegyede számolt be szándékos fizikai önsértő viselkedésről, vagyis hússzor annyian, mint a depressziós kontrollszemélyek. A borderline betegek serdülőkorban kezdték az önsebzést, és életük során nagyon gyakran, átlagosan harmincszor követtek el fizikai önsértést.

Vizsgálatunkban az önsértő viselkedés kialakulásának esélyét a gyermekkori traumatikus élmények halmozódása és a disszociáció növelték jelentősen. A szándékos önsértés és a traumatizáció szoros kapcsolatát korábbi kutatásokban már igazolták [27-31]. Az önsértés a korai traumatizáció következtében deficites érzelemreguláció pótlására szolgál, és maladaptív megküzdésként értelmezhető [44]. A cselekmény elkövetése paradox módon megkönnyebbüléssel jár, felülírja, elfedi az érzelmi fájdalmat; szolgálhatja a kontrollérzet elnyerését az érzelmileg elárasztó helyzetekben [24, 45]; segíthet csillapítani, kifejezni, igazolni az elviselhetetlen feszültséget, dühöt; oldhatja a kiüresedett állapotokat [16, 46-48], valamint láthatóvá teszi, konkretizálja az érzelmi fájdalmat [19]. A fizikai önsértés jelentőségét sokszor alábecsülik, mivel gyakran nyilvánvaló, hogy nem hordoz az életet veszélyeztető kockázatot, vagy manipulatív szándékot tulajdonítanak neki. Az önsértés valójában arra figyelmeztet, hogy a beteg nagy eséllyel traumatizált és disszociatív munkamódokat alkalmaz.

Vizsgálatunkban újszerű megállapítás, hogy nemcsak a trauma megtörténte vagy hiánya, hanem (az abúzus súlyossági paraméterei mellett) az egyes traumatípusok halmozódása jelenti a legnagyobb kockázatot az önsértések és disszociatív múködésmódok kialakulása szempontjából.

Kutatásunk arra hívja fel a figyelmet, hogy hazánkban is gyakori a súlyos, komplex gyermekkori traumatizáció a borderline betegek körében. A borderline pszichopatológia és a társuló zavarok - legalábbis a súlyosabb, hospitalizációt igénylő betegek esetében - komplex poszttraumás stressz zavarként értelmezhetőek, és ennek megfelelő, háromfázisú traumaterápiát igényelnek.

Eredményeink tágabb értelemben a titokban maradó, fel nem ismert gyermekkori traumatizáció elterjedtségé- re és kórnemző szerepére világítanak rá, amely nemcsak az itt tárgyalt borderline betegek személyiségfejlődését károsítja, hanem a klinikai populáció széles körét érinti, és feltehetően a kezelést soha nem kereső átlagpopulációban is sokan szenvednek ezektől az ártalmaktól [38].

A borderline személyiségzavar jelentős népegészségügyi problémát képvisel, a páciensek gyakran keresnek önként orvosi segítséget, és az ambuláns kezelések mellett gyakran részesülnek sürgősségi ellátásban. A borderline betegek nehezen illeszkednek be a társadalomba, nem fejezik be tanulmányaikat, gyakorta váltogatják munkahelyeiket, valamint az indulatkitörések, az önsértő viselkedés, a szuicid kísérletek és a nagyfokú érzelmi labilitás miatt az orvosok és az egészségügyi szakszemélyzet számára frusztrációt és nehézségforrást jelentenek. Vizsgálatunkkal a borderline személyekre jellemző, látszólag értelmetlen és regresszív múködések hátterében álló dinamikára szeretnénk felhívni a szakemberek figyelmét, és elősegíteni, hogy az alapellátásban vagy az egészségügyi ellátás más területein felismerjék, megértsék, megfelelően kezeljék, és ezáltal jobb életminőséghez segítsék hozzá ezt a nehéz betegcsoportot.

Anyagi támogatás: A kutatás az Európai Unió és Magyarország támogatásával a TÁMOP 4.2.4.A/2-11-12012-0001 azonosítószámú „Nemzeti Kiválóság Program - Hazai hallgatói, illetve kutatói személyi támogatást biztosító rendszer kidolgozása és múködtetése konvergencia program" címú kiemelt projekt keretei között valósult meg.

Szerzôi munkamegosztás: M. K.: A vizsgálat tervezése és lefolytatása, a kézirat megszövegezése. H. J.: A vizsgálat feltételeinek biztosítása, lefolytatásának segítése. P. G.: Statisztikai elemzések. K. Sz. I.: A vizsgálat tervezése, a kézirat megszövegezése. A cikk végleges változatát valamennyi szerző elolvasta és jóváhagyta.

Érdekeltségek: A szerzőknek nincsenek érdekeltségeik.

\section{Irodalom}

[1] Quirk, S. E., Berk, M., Chanen, A. M., et al.: Population prevalence of personality disorder and associations with physical health comorbidities and health care service utilization: A review. Personal. Disord., 2016, 7(2), 136-146. [Epub 2015 Oct 12]

[2] Gunderson, J. G., Links, P. S.: Borderline personality disorder: A clinical guide. American Psychiatric Publishing Inc., Arlington, 2009.

[3] Kuritárné Szabó, I.: Borderline personality disorder. Symptoms, etiology, therapy. [Borderline személyiségzavar. Tünettan, etiológia, terápia.] Medicina Könyvkiadó, Budapest, 2008.

[4] Putnam, F. W.: Ten-year research update review: Child sexual abuse. J. Am. Acad. Child Adolesc. Psychiatry, 2003, 42(3), 269-278.

[5] Machizawa-Summers, S.: Childhood trauma and parental bonding among Japanese female patients with borderline personality disorder. Int. J. Psychol., 2007, 42(4), 265-273. 
[6] Sansone, R. A., Lam, C., Wiederman, M. W.: Being bullied in childhood: correlations with borderline personality in adulthood. Compr. Psychiatry, 2010, 51(5), 458-461.

[7] Zhang, T. H., Chow, A., Wang, L. L., et al.: Childhood maltreatment profile in a clinical population in China: A further analysis with existing data of an epidemiologic survey. Compr. Psychiatry, 2012, 54(7), 856-864.

[8] Merza, K., Papp, G., Kuritárné Szabó, I.: The role of childhood traumatization in the development of borderline personality disorder in Hungary. Eur. J. Psychiat., 2015, 29(2), 105-118.

[9] Westen, D., Ludolph, P., Misle, B., et al.: Physical and sexual abuse in adolescent girls with borderline personality disorder. Am. J. Orthopsychiatry, 1990, 60(1), 55-66.

[10] American Psychiatric Association: Diagnostic and statistical manual of mental disorders: DSM-5. American Psychiatric Association, Washington, DC, 2013.

[11] Korzekwa, M. I., Dell, P. F., Pain, C.: Dissociation and borderline personality disorder: an update for clinicians. Curr. Psychiatry Rep., 2009, 11(1), 82-88.

[12] Van der Hart, O., Nijenhuis, E., Steele, K., et al.: Trauma-related dissociation: conceptual clarity lost and found. Aust. N. Z. J. Psychiatry, 2004, 38(11-12), 906-914.

[13] Brodsky, B. S., Cloitre, M., Dulit, R. A.: Relationship of dissociation and childhood abuse in borderline personality disorder. Am. J. Psychiatry, 1995, 152(12), 1788-1792.

[14] Draijer, N., Langeland, W.: Childhood trauma and perceived parental dysfunction in the etiology of dissociative symptoms in psychiatric inpatients. Am. J. Psychiatry, 1999, 156(3), 379-385.

[15] Van der Kolk, B. A., Pelcovitz, D., Roth, S., et al.: Dissociation, somatization, and affect dysregulation: the complexity of adaptation of trauma. Am. J. Psychiatry, 1996, 153(7 Suppl.), 83-93.

[16] Herman, J. L.: Trauma and recovery. [Trauma és gyógyulás.] Háttér Kiadó, Budapest, 2011. [Hungarian]

[17] Foote, B., Smolin, Y., Kaplan, M., et al.: Prevalence of dissociative disorders in psychiatric outpatients. Am. J. Psychiatry, 2006, $163(4), 623-629$.

[18] Vermetten, E., Spiegel, D.: Trauma and dissociation: implications for borderline personality disorder. Curr. Psychiatry Rep., 2014, $16(2), 434$

[19] Kuritárné Szabó, I.: Characteristics of borderline suicidality. [A borderline szuicidalitás jellegzetességei.] Psychiatr. Hung., 2008, 23(1), 22-33. [Hungarian]

[20] Dubo, E., Zanarini, M. C., Lewis, R. E., et al.: Relationship between lifetime self-destructiveness and pathological childhood experiences. In: Role of sexual abuse in the etiology of borderline personality disorder. Ed: Zanarini, M. C. American Psychiatric Press, Washington, DC, 1997, 107-130.

[21] Sansone, R.: Chronic suicidality and borderline personality disorder. J. Pers. Disord., 2004, 18(3), 215-225.

[22] Brodsky, B. S., Malone, K. M., Ellis, S. P., et al.: Characteristics of borderline personality disorder associated with suicidal behavior. Am. J. Psychiatry, 1997, 154(12), 1715-1719.

[23] Silk, K., Nigg, J. T., Westen, D., et al.: Severity of childhood sexual abuse, borderline symptoms, and familiar environment. In: Role of sexual abuse in the etiology of borderline personality disorder. Ed: Zanarini, M. C. American Psychiatric Press, Washington, DC, 1997, 131-164.

[24] Van der Kolk, B. A., Perry, J. C., Herman, J. L.: Childhood origins of self-destructive behavior. Am. J. Psychiatry, 1991, 148(12), 1665-1671.

[25] Zanarini, M. C., Yong, L., Frankenburg, F. R., et al.: Severity of reported childhood sexual abuse and its relationship to severity of borderline psychopathology and psychosocial impairment among borderline inpatients. J. Nerv. Ment. Dis., 2002, 190(6), 381-387.

[26] Pettigrew, J, Burcham, J.: Effects of childhood sexual abuse in adult female psychiatric patients. Aust. N. Z. J. Psychiatry, 1997, $31(2), 208-213$.
[27] Romans, S. E., Martin, J. L., Anderson, J. C., et al.: Sexual abuse in childhood and deliberate self-harm. Am. J. Psychiatry, 1995, 152(9), 1336-1342.

[28] Matsumoto, T., Azekawa, T., Yamaguchi, A., et al.: Habitual selfmutilation in Japan. Psychiatry Clin. Neurosci., 2004, 58(2), 191-198.

[29] Zanarini, M. C., Laudate, C. S., Frankenburg, F. R., et al.: Predictors of self-mutilation in patients with borderline personality disorder: A 10-year follow-up study. J. Psychiatr. Res., 2011, 45(6), 823-828.

[30] Zlotnick, C., Mattia, J. I., Zimmerman, M.: Clinical correlates of nonsuicidal self-injury in a sample of general psychiatric patients. J. Nerv. Ment. Dis., 1999, 187(5), 296-301.

[31] Zweig-Frank, H., Paris, J.: Relationship of childhood sexual abuse to dissociation and nonsuicidal self-injury in female patients. In: Role of sexual abuse in the etiology of borderline personality disorder. Ed: Zanarini, M., C. American Psychiatric Press, Washington, DC, 1997, 93-106.

[32] First, M. B., Szádóczky, E., Rózsa, S., et al.: Structured Clinical Interview for DSM-IV Axis I disorders. [SCID-I: Strukturált klinikai interjú a DSM-IV I. tengely zavarainak felmérésére. Klinikai változat: kézikönyv.] OS Hungary Tesztfejlesztő, Budapest, 2006. [Hungarian]

[33] First, M. B., Szádóczky, E., Unoka, Zs., et al.: Structured Clinical Interview for DSM-IV Axis II disorders. [SCID-II: Strukturált klinikai interjú a DSM-IV II. tengelyén található személyiségzavarok felmérésére.] OS Hungary Tesztfejlesztő, Budapest, 2004. [Hungarian]

[34] Van der Kolk, B. A., Smyth, N.: Trauma Assessment Packet (CDROM). The Trauma Center at Justice Resource Institute, University of Buffalo School of Social Work, Brookline, MA, 2010.

[35] Bremner, J. D., Bolus, R., Mayer, E. A.: Psychometric properties of the Early Trauma Inventory - Self Report. J. Nerv. Ment. Dis., 2007, 195(3), 211-218.

[36] Csorba, J., Szélesné Ferencz, E., Steiner, P., Németh, Á.: Symptom specificity of adolescents with self-injurious behavior. [Önsértő magatartású középiskolás serdülő́k tüneti jellegzetességei.] Psychiatr. Hung., 2005, 20(6), 456-462. [Hungarian]

[37] Varga, K., Osvát, J., Vanderlinden, J.: The concept of dissociation, and its measures. The Hungarian version of the Dissociation Questionnaire. [A disszociáció fogalma, mérése és a „Disszociáció Kérdőív" (DISQ-H) bemutatása.] Magyar Pszichológiai Szemle, 1996, 52(1-3), 125-150. [Hungarian]

[38] Asmussen, K. National Society for the Prevention of Cruelty to Children: Key facts about child maltreatment. NSPCC, London, 2010.

[39] Galletly, C.: Borderline-dissociation comorbidity. Am. J. Psychiatry, 1997, 154(11), 1629.

[40] Paris, J. P., Zweig-Frank, H.: Parameters of childhood sexual abuse in female patients. In: Role of sexual abuse in the etiology of borderline personality disorder. Ed: Zanarini, M., C. American Psychiatric Press, Washington, DC, 1997, 15-18.

[41] Nijenhuis, E. R., van der Hart, O., Steele, K.: Trauma related structural dissociation of the personality. Trauma Information Pages website, January 2004. Web URL: http://www.traumapages.com/a/nijenhuis-2004.php

[42] Ford, J. D., Gómez, J. M.: The relationship of psychological trauma and dissociative and posttraumatic stress disorder to nonsuicidal self-injury and suicidality: a review. J. Trauma Dissociation, 2015, 16(3), 232-271.

[43] Sar, V., Akyuz, G., Kugu, N., et al.: Axis I dissociative disorder comorbidity in borderline personality disorder and reports of childhood trauma. J. Clin. Psychiatry, 2006, 67(10), 15831590.

[44] Stanley, B., Brodsky, B. S.: Suicidal and self-injurious behavior in borderline personality disorder: a self-regulation model. In: Understanding and treating borderline personality disorder. Eds: 
Gunderson, J. G., Hoffman, P. D. American Psychiatric Publishing, Inc., Washington, DC, 2005, 43-64.

[45] Klonsky, E. D.: The functions of self-injury in young adults who cut themselves: Clarifying the evidence for affect-regulation. Psychiatry Res., 2009, 166(2-3), 260-268.

[46] Nixon, M. K., Cloutier, M. A., Aggrawal, S.: Affect regulation and addictive aspects of repetitive self-injury in hospitalized adolescents. J. Am. Acad. Child Adolesc. Psychiatry, 2002, 4l(11), 1333-1341

[47] Paivio, S. C., McCulloch, C. R.: Alexithymia as a mediator between childhood trauma and self-injurious behaviors. Child Abuse Negl., 2004, 28(3), 339-354.
[48] Zanarini, M. C., Laudate, C. S., Frankenburg, F. R., et al.: Reasons for self-mutilation reported by borderline patients over 16 years of prospective follow-up. J. Pers. Disord., 2013, 27(6), 783-794.

(Merza Katalin,

Debrecen, Nagyerdei krt. 98., 4032 e-mail: merza.katalin@sph.unideb.hu)

Új fejlesztés az egészségügyben dolgozók, tanulók részére!

A magyar nyelvứ szakirodalmi keresőszolgáltatás

\section{Mi a NOTA?}

Napivizit Orvosi Tudástár Alkalmazás

Mit tud a NOTA portál?

Megkönnyíti a magyar nyelvú szakirodalmi források keresését.

Eszköztől függetlenül, akár okostelefonról, a betegágy mellett állva is használható.

\section{Miben kereshet a NOTA-val?}

Az Akadémiai Kiadó folyóirataiban: Orvosi Hetilap, Magyar Sebészet, Mentálhigiéné és Pszichoszomatika.

Más kiadók magyar nyelvű szakfolyóirataiban: pl. Lege Artis Medicinae, Hypertonia és Nephrologia, Ideggyógyászati Szemle.

A hatályos szakmai irányelvekben.

Magyar nyelvủ kérdésekre adott ango nyelvű találatokban, a PubMeden.

\section{nota.hu}

Amennyiben további információra lenne szüksége, keressen minket elérhetöségeinken:
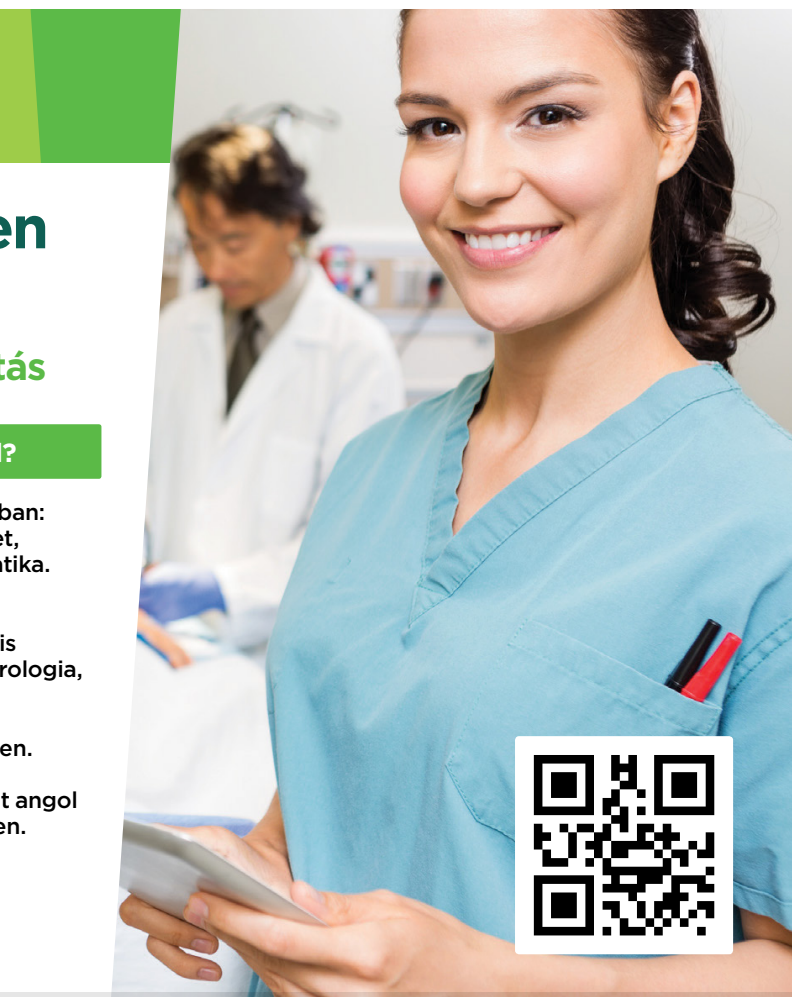

Akadémiai Kiadó

A Wolters Kluwer Csoport tagja

1117 Budapest, Prielle Kornélia u. 21-35. / Telefon: (1) 464-8246

www.akademiai.hu / www.akademiai.com

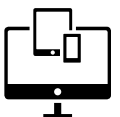

$\prod$ NOTA

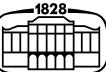

AKADÉMIAI KIADÓ 